\title{
ETLINGERA COMOSA, A NEW SPECIES (ZINGIBERACEAE: ALPINIOIDEAE) FROM CENTRAL SULAWESI
}

Received October 31, 2021; accepted December 07, 2021

MARLINA ARDIYANI

Herbarium Bogoriense, Research Center for Biology, National Research and Innovation Agency. Jln. Raya JakartaBogor, Km.46, Cibinong 16911,WestJava.Email:marl004@brin.go.id

\section{WISNU HANDOYO ARDI}

Research Center for Plant Conservation and Botanic Gardens, National Research and Innovation Agency. Jln. Ir. H. Juanda No.13, Bogor16122.Email:wisn005@brin.go.id

\section{PRIMA WAHYU KUSUMA HUTABARAT}

Research Center for Plant Conservation and Botanic Gardens, National Research and Innovation Agency. Jln. Ir. H. Juanda No. 13, Bogor 16122. Email: prim003@brin.go.id

\section{AXEL DALBERG POULSEN}

Royal Botanic Garden Edinburgh, 20 A Inverleith Row, Edinburgh EH3 5LR, Scotland, United Kingdom.

Email:axel@dalbergpoulsen.com

\begin{abstract}
ARDIYANI, M., ARDI, W. H., HUTABARAT, P. W. K. \& POULSEN, A. D. 2021. Etlingera comosa, a new species (Zingiberaceae: Alpinioideae) from Central Sulawesi. Reinwardtia 20(2): 63-68. - Etlingera comosa Ardiyani \& Ardi, a new and unusual species from Tentena, Central Sulawesi exhibiting terrestrial as well as epiphytic habit is described here. It is compared to the morphologically closest Etlingera sublimata A.D.Poulsen, but differs in having tufted sheath, bilobed and asymmetric ligule, loose peduncular bracts, densely pubescent fertile bracts and longer filament. Colour plates, notes on its conservation status and DNA barcode data for the new species are also provided.
\end{abstract}

Key words: Acanthodes group, DNA barcode, epiphytic, Etlingera sublimata, Indonesia, Zingiberales.

\begin{abstract}
ABSTRAK
ARDIYANI, M., ARDI, W. H., HUTABARAT, P. W. K. \& POULSEN, A. D. 2021. Etlingera comosa, satu jenis baru (Zingiberaceae: Alpinioideae) dari Sulawesi Tengah. Reinwardtia 20(2): 63-68. — Etlingera comosa Ardiyani \& Ardi merupakan sebuah jenis baru dan unik yang berasal dari Tentena, Sulawesi Tengah dengan perawakan terestrial sekaligus epifit. Jenis ini dibandingkan dengan jenis yang mempunyai kedekatan morfologi yaitu Etlingera sublimata A.D.Poulsen, namun berbeda dalam karakter pelepah yang berumbai, ligula yang bercuping dua dan asimetrik, daun gagang longgar, daun gagang fertil berbulu balig rapat dan tangkai sari lebih panjang. Foto berwarna dan catatan mengenai status konservasi dan data kode batang DNA untuk jenis baru ini juga disajikan.
\end{abstract}

Kata kunci: Epifitik, Etlingera sublimata, grup Acanthodes, Indonesia, kode batang DNA, Zingiberales.

\section{INTRODUCTION}

Etlingera Giseke (Zingiberaceae) is a genus with more than 100 species worldwide. The number of species have increased significantly in recent years, especially in Sulawesi, Indonesia, as more explorations of the island were done. The genus is distributed from India, Indo-China throughout Malesia to the Pacific Islands (Poulsen, 2012; Poulsen \& Docot, 2018). A revision of the genus was carried out by Poulsen for Etlingera of
Borneo (Poulsen, 2006), Java (Poulsen, 2007) and Sulawesi (Poulsen, 2012). Poulsen (2012) included 46 species of Etlingera in Sulawesi. Seven years later, a new species, E. mamasarum A.D.Poulsen \& Ardiyani, was discovered from Mamasa, West Sulawesi (Ardiyani \& Poulsen, 2019). The following year, Etlingera tjiasmantoi Ardiyani \& Ardi was found in Central Sulawesi (Ardiyani et al., 2020). Thus, 48 species of Etlingera are currently known in Sulawesi. 
During the expedition carried out in early 2020 by the first three authors to Central Sulawesi an interesting species of Etlingera was found on mossy logs and epiphytically on a tree trunk. At first, this looked very similar to E. sublimata, but a more thorough examinations revealed that it differs from it in several important characters, and furthermore does not match any other Etlingera species. Therefore, it is here described as a new species. A colour plate, notes on its conservation status and the DNA barcode of this new species are provided.

\section{MATERIALS AND METHODS}

The fieldwork was carried out in March 2020 in Central Sulawesi. The locality can be seen in Fig. 1. Herbarium specimens were prepared in the field including pickling flowers and inflorescence in $70 \%$ alcohol and photos of the floral dissection. Leaf tissue material was dried in silica gel for the purpose of molecular analyses (Wilkie et al., 2013). Morphological characters were noted from the living plant in the wild as well as from the herbarium specimens in BO. Measurements were made using a ruler and a calibrated eyepiece under a dissecting microscope. DNA barcoding was done using rbcL, matK, the Intergenic Spacers between trnH and psbA (Kress \& Erickson, 2007), and the Internal Transcribed Spacers (ITS) (Kress et al., 2005). The barcode protocols followed Kress \& Erickson (2012). DNA sequencing was done in the 1stBase company, and the sequences obtained were deposited in the NCBI GenBank (Table 2).

\section{RESULTS AND DISCUSSION}

Etlingera comosa Ardiyani \& Ardi spec. nov. Fig. 2. - TYPE: INDONESIA, Central Sulawesi Province, Tentena Regency, roadside between Tentena and Bada, elevation $1,700 \mathrm{~m}, 01.80429 \mathrm{~S}$, $120.47046 \mathrm{E}$, flowering and fruiting, 7 March 2020, M. Ardiyani, Wisnu H. Ardi, Prima Hutabarat, Zulfadli, Roland Putra, Ofin MAR1004 (Holotype BO!).

Similar to Etlingera sublimata A.D.Poulsen by the spiny bracts and thecae dehiscent through their entire length but $E$. comosa differs from E. sublimata in having tufted sheath (vs. not tufted), bilobed, asymmetric ligule (vs. entire), peduncular bracts only loosely enclosing base of spike and partly exposed the axis (vs. peduncular bracts

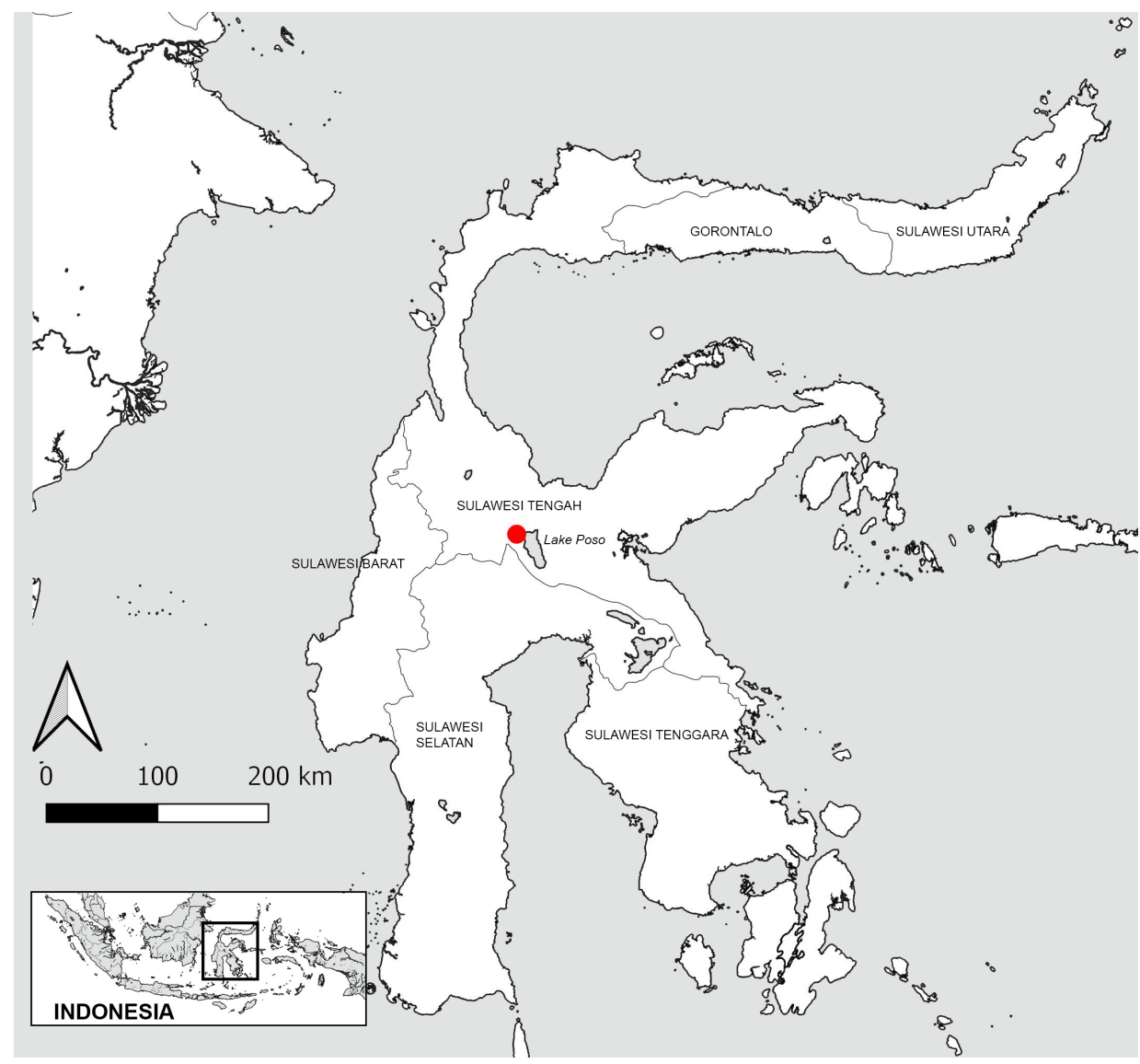

Fig. 1. The type locality of Etlingera comosa in Tentena, Central Sulawesi. 

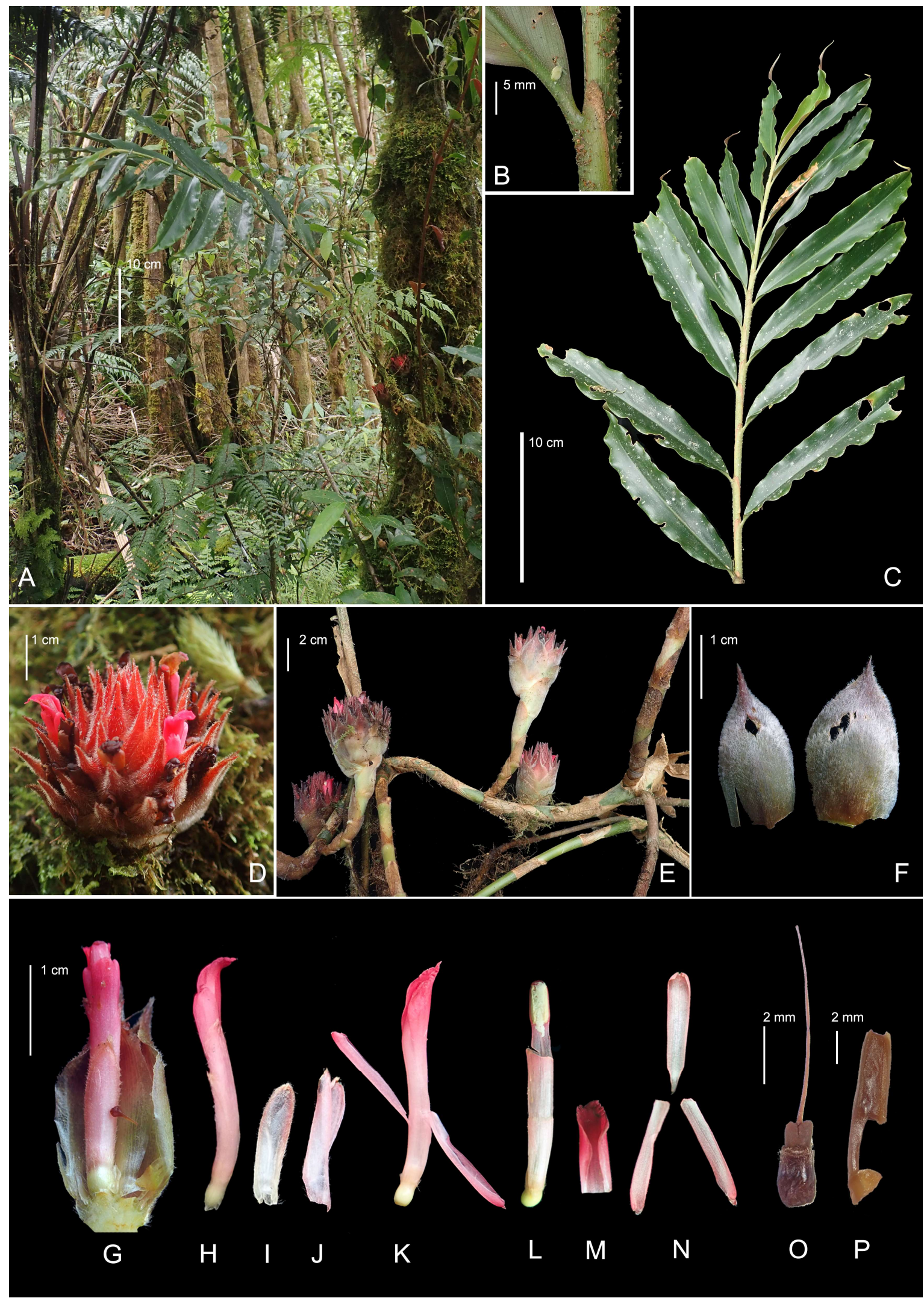

Fig. 2. Etlingera comosa Ardiyani \& Ardi spec. nov. A. Habit. B. Pseudostem, ligule and petiole. C. Leaves (upper surface). D. Inflorescence with three freshly opened flowers (semi-lateral view). E. Base of leafy shoot and inflorescence arising from the rhizome. F. Sterile bracts. G. Fertile bract, bracteole and flower. H. Flower. I. Bracteole. J. Calyx. K. Flower with brateole and calyx removed. L. Flower with calyx, corolla lobes and labellum removed. M. Labellum. N. Corolla lobes. O. Ovary, epigynous glands, style and stigma. P. Filament, anther and part of staminal tube (lateral view). From M. Ardiyani et al. 1004. Photos by Marlina Ardiyani \& Wisnu H. Ardi. 
enclosing base of spike, peduncle axis not exposed), fertile bracts densely pubescent (vs. glabrous with ciliate margin), longer stamen ( 9 $\mathrm{mm} v s .5 \mathrm{~mm})$, longer filament $(3.5-4.5 \mathrm{~mm} v s$. $0.5 \mathrm{~mm}$ ) and shorter anther (4 $\mathrm{mm} v s .5-5.5 \mathrm{~mm})$.

Terrestrial or epiphytic herb. Rhizome $0.5 \mathrm{~cm}$ diam. when dried, densely pubescent, green, scales 1.3-2.8 cm long, velvety; stilt roots $3 \mathrm{~mm}$ diameter when dried, brown, raising the rhizome to about $25 \mathrm{~cm}$ above ground. Leafy shoots to 70 $\mathrm{cm}$ long, 15-20 cm apart; base to $1.5 \mathrm{~cm}$ diameter, light green covered with dry scales; sheath greenish yellow with brown margin, tufted, margin fimbriate; ligule 3-4 mm long, bilobed, asymmetric, greenish yellow with brown dry edge, puberulous, margin ciliate; petiole 2-4 mm long, yellowish green, puberulous, some tufted; lamina 15-19 $\times$ $2.7-3.3 \mathrm{~cm}$, length to width ratio 5.6-5.7, dark green above, light green with reddish brown tinge beneath, glabrous above and beneath, midrib puberulous beneath; base cuneate; apex caudate; margin glabrous, undulate. Flowering shoot 9.5$10 \mathrm{~cm}$ long, arising from rhizome, erect, receptacle with \pm 50 flowers, flowers open at a time; peduncle $5.5 \mathrm{~cm}$ long, ascending, sericeous, peduncular bracts $0.7-2 \times 0.6-1.1 \mathrm{~cm}$, loosely adhering, not fully enclosing base of spike exposing the axis, greenish yellow towards base, pale brown towards apex when young, pale brown when old, densely sericeous above, glabrous beneath, obovoid, flowers reaching $0.3 \mathrm{~cm}$ longer than the bracts; sterile bracts $2.4-3 \times 2-3 \mathrm{~cm}$, broadly obovate, boat-shaped, mucronate (mucro 3-4 mm long), apex acute, green, densely pubescent above, glabrous beneath; fertile bracts 2.6$3.2 \times 1.2-2.2 \mathrm{~cm}$, obovate, boat-shaped, apex aristate, with 4-5 mm long mucro, green, densely pubescent above, glabrous beneath; pedicel absent; bracteole 1.6-1.8 cm long, membranous, pale pink, 1 fissure, sericeous, apex 1-lobed, mucronate. Flower 2.6-2.9 cm long; calyx $1.7 \mathrm{~cm}$ long, contracted at base, reaching to base of stamen and 3-4 mm short of apex of corolla lobes, pale pink, with 2 fissures of $0.3-0.4 \mathrm{~cm}$, moderately hairy, apex 3 -toothed, apices finely mucronate and ciliate; corolla tube $1.5-1.6 \mathrm{~cm}$ long, pale pink, glabrous, with a few scattered hairs inside; lobes pale pink at base, pink towards apex, narrowly ovate, glabrous with scattered hair at apex, apex slightly cucullate, dorsal lobe 11-18 × 3-4 $\mathrm{mm}$ long (reaching $2 \mathrm{~mm}$ short to $3 \mathrm{~mm}$ beyond apex of anther), lateral lobes $17 \times 3-3.5 \mathrm{~mm}$; staminal tube $7 \mathrm{~mm}$ long, pale pink; labellum ovate, 9-11 × $6 \mathrm{~mm}$ when flattened, red, glabrous, lateral lobe margin involute or erect \pm covering the stamen, central lobe entire, slightly recurved, extending $3 \mathrm{~mm}$ beyond anther when flattened; stamen 6 $\mathrm{mm}$ long, pale pink; filament $2 \times 2 \mathrm{~mm}$; anther $4 \times$ $2 \mathrm{~mm}$, parallel-sided, spurred, angled $165^{\circ}-170^{\circ}$, anther crest emarginate; thecae completely dehiscent (slit ca. $4 \mathrm{~mm}$ ), sericeous along slits and apex; ovary $3 \times 2 \mathrm{~mm}$, barrel-shaped, pale greenish yellow, glabrous at base, ciliate towards apex; epigynous gland $1.5-2 \mathrm{~mm}$ long, split to base adaxially, emarginate, glabrous; style $2.2-2.5 \mathrm{~cm}$ long, white, papillose especially towards apex; stigma 1 mm wide, pink, club-shaped, ostiole transverseelliptic less than $1 \mathrm{~mm}$, facing downwards, puberulous. Infructescence not seen.

Distribution. Only known from the type locality in Tentena, Central Sulawesi, Indonesia.

Habitat. Slopes in secondary, upper montane, very humid forest with open canopy less than 10 $\mathrm{m}$. Most tree trunks were covered with mosses, open areas with many ferns and ericaceous shrubs, such as species of Rhododendron, Vaccinium and Gaultheria.

Etlingera comosa was quite common in this vegetation and many individuals were encountered (in one spot $>25$, including juveniles) most of which grew on moss-covered dead tree trunks, or on bases of trees. The single flowering individual found was epiphytic. In this moist and open forest type, it is not surprising to see species occurring both terrestrially and as epiphytes.

Etymology. The epithet comosa refers to the tufted hairs of the sheath.

Phenology. Flowering in March.

Local name \& uses. Not available.

Conservation status. This species is currently only known from the type locality, which is not in a conserved area and close to the main road between Tentena and Bada. There is a possibility that the population will decline in the future if the area is not conserved. The conservation status is therefore tentatively assigned as Vulnerable D2 (IUCN, 2021).

Notes. With its montane habit, sessile and barrelshaped ovary, pink and glabrous labellum, and the anther dehiscing for its entire length, Etlingera comosa clearly belongs to the Acanthodes group, which up till now consists of 15 species in 
Table 1. Morphological characters of Etlingera sublimata and E. comosa.

\begin{tabular}{|c|c|c|c|}
\hline No & Characters & Etlingera sublimata (Poulsen 2012) & Etlingera comosa \\
\hline 1 & Indumentum of sheath & Puberulous & Tufted \\
\hline 2 & Ligule shape & Entire & Bilobed, asymmetric \\
\hline 3 & Petiole length & Sessile & $2-4 \mathrm{~mm}$ \\
\hline 4 & Position of peduncular bracts & $\begin{array}{l}\text { Enclosing base of spike, uppermost } \\
\text { the longest; imbricate, peduncle not } \\
\text { exposed }\end{array}$ & $\begin{array}{l}\text { Not fully enclosing base of } \\
\text { spike; loose, peduncle is } \\
\text { partly exposed }\end{array}$ \\
\hline 5 & Colour of peduncular bracts & Pale brown & $\begin{array}{l}\text { Greenish yellow towards } \\
\text { base, pale brown towards } \\
\text { apex when young, pale } \\
\text { brown when old }\end{array}$ \\
\hline 6 & Indumentum of fertile bracts & Glabrous, margin ciliate & $\begin{array}{l}\text { Densely pubescent, margin } \\
\text { ciliate }\end{array}$ \\
\hline 7 & Stamen length $(\mathrm{mm})$ & 5 & 9 \\
\hline 8 & Filament dimensions $(\mathrm{mm})$ size & $0.5 \times 2-2.5 \mathrm{~mm}$ & $3.5-4.5 \times 2 \mathrm{~mm}$ \\
\hline 9 & Anther dimensions (mm) & $5-5.5 \times 2.3-3 \mathrm{~mm}$ & $4 \times 2 \mathrm{~mm}$ \\
\hline
\end{tabular}

Table 2. DNA barcoding of Etlingera comosa

\begin{tabular}{ccccc}
\hline \multirow{2}{*}{ Species } & \multicolumn{4}{c}{ NCBI GenBank Accession No. } \\
\hline \multirow{2}{*}{ Etlingera comosa } & $r b c L$ & ITS & trnH-psbA & matK \\
& OL631135 & OL711629 & OL752579 & OL770275 \\
\hline
\end{tabular}


Sulawesi (Poulsen, 2012). Of these, the following species have spiny bracts: Etlingera acanthodes A.D.Poulsen, E. chlorodonta A.D.Poulsen, E. doliiformis A.D.Poulsen, E. mucronata A.D.Poulsen, E. spinulosa A.D.Poulsen and E. sublimata A.D.Poulsen. The latter is most similar, but $E$. comosa differs from it by the striking tufted indumentum on the sheath, the hairy bracts, ligule shape, stamen length as well as other morphological differences (Table 1).

The original description of E. sublimata mentions the tessellate pattern of the leaf sheath but omitted that the sheath is more or less uniformly puberulous, which is clearly observed on the neotype (Poulsen et al. 2647, BO!, E!). It is, in any case, strikingly different to the tufted sheath of E. comosa. This character has, however, also been described in other species of the Acanthodes Group, such as E. spinulosa and E. steringophora. Etlingera comosa is morphologically dissimilar to these species and can be distinguished by multiple characters such as the bilobed and asymmetric ligule with puberulous hairs vs. 19-21 mm, emarginate ligule with vilose hairs (E. steringophora) and $22-26 \mathrm{~mm}$ long, inflated, bilobed ligule and laterally extended to clasp the pseudostem (E. spinulosa); smaller lamina $(15-19 \times 2.7-3.3$ cm) vs. 35-35 $\times 4.5-6 \mathrm{~cm}$ in E. steringophora and $63 \times 16 \mathrm{~cm}$ in E. spinulosa). The shape of fertile bract and anther size are further differences. In E. comosa, the fertile bracts are obovate with aristate apex $v s$. broadly spatulate with mucronate apex (E. steringophora) and ovate with long acute apex (E. spinulosa). The E. comosa anther size is ca. $4 \times 2 \mathrm{~mm}$, while it is $6 \times 3 \mathrm{~mm}$ in E. spinulosa and $5.5 \times 3 \mathrm{~mm}$ in E. steringophora.

\section{ACKNOWLEDGEMENTS}

We thank to the Research Center for Biology, National Research and Innovation Agency (BRIN) and the Research Center for Plant Conservation and Botanic Gardens, National Research and Innovation Agency (BRIN) for the support and permission given to us to carry out botanical inventory in Central Sulawesi. We are indebted to the BKSDA of Central Sulawesi for the collection permit; to Rolland Putra and Zulfadli for their help in the field; to Susila who helped us with the molecular work. Finally, we thank Dr. Wewin Tjiasmanto who gave us financial supports. The fourth author was not involved in the fieldwork.

\section{REFERENCES}

ARDIYANI, M. \& POULSEN, A. D. 2019. An update of the genus Etlingera (Zingiberaceae) in Sulawesi including the description of a new species. Reinwardtia 18(1): 49-60.

DOI: 10.14203/reinwardtia.v18i1.3729.

ARDIYANI, M., ARDI, W. H., SANTOSO, W. \& POULSEN, A. D. 2020. Etlingera tjiasmantoi (Zingiberaceae), a new species from Central Sulawesi. Reinwardtia 19(2): 103-108.

DOI: 10.14203/reinwardtia.v19i2.3972.

IUCN. 2021. The IUCN Red List of Threatened Species. Version 2021-2. https://www.iucnred list.org. (Downloaded 1 August 2021).

KRESS, W. J., WURDACK, K. J., ZIMMER, E. A., WEIGT, L. A. \& JANZEN, D. H. 2005. Use of DNA barcodes to identify flowering plants. PNAS 102(23): 8369-8374. DOI: 10.1073/pnas. 0503123102.

KRESS, W. J. \& ERICKSON, D. L. 2007. A twolocus global DNA barcode for land plants: The coding $r b c \mathrm{~L}$ gene complements the non-coding trnH-psbA spacer region. PLoS ONE 2: e508.

KRESS, W. J. \& ERICKSON, D. L. 2012. DNA Barcodes: Methods and Protocols. Series Methods in Molecular Biology. Humana Press, Springers.

POULSEN, A. D. 2006. Etlingera of Borneo. Natural History Publications (Borneo), Kota Kinabalu, Malaysia.

POULSEN, A. D. 2007. Etlingera Giseke of Java. Garden's Bulletin Singapore 59 (1\&2): 145172.

POULSEN, A. D. 2012. Etlingera of Sulawesi. Natural History Publications (Borneo). Kota Kinabalu, Malaysia.

POULSEN, A. D. \& DOCOT, R. V. A. 2018. How many species of Etlingera (Zingiberaceae) are there in the Philippines? Edinburgh Journal of Botany 76: 33-44.

WILKIE, P., POULSEN, A. D., HARRIS, D. \& FORREST, L. L. 2013. The collection and storage of plant material for DNA extraction: the teabag method. Gardens' Bulletin Singapore 65 (2): 231-234. 